\title{
ENHANCEMENT OF YIELD, STARCH, AND AMYLOSE CONTENT OF TWO INDONESIAN CASSAVA GENOTYPES BY PRODUCING GAMMA IRRADIATED-INDUCED MUTANTS
}

\author{
Enny Sudarmonowati*, N. Sri. Hartati, Supatmi \\ Research Centre for Biotechnology - Indonesian Institute of Sciences (LIPI) \\ Jl. Raya Bogor Km. 46 Cibinong 16911. Indonesia
}

\begin{abstract}
As an important carbohydrate-source food crop and raw materials of starch-based industries, accelerated cassava breeding has been extensively pursued through various procedures, among others, is mutant induction using gamma irradiation combined with molecular marker. Iding, a local genotype cassava has been compared with a national variety Adira 4 for its yield attributes following gamma irradiation at various dose levels ( 2,20 , 30 , and $50 \mathrm{krad})$. The mutation rate was conducted based on morphological characteristics and identification using RAPD by employing random primer OPB-10. Evaluation was conducted on mutant lines producing high potential yield, high starch and amylose contents. The fourth generation of irradiated Adira 4 (2 and $30 \mathrm{krad})$ and Iding $(2 \mathrm{krad})$ exhibited higher yield and amylose content as compared to their representative controls. The yield of $30 \mathrm{krad}$ irradiated Adira 4 indicated by mean tuber weight per individual could reach more than twice of that of control and almost 1.5 times of that irradiated with $2 \mathrm{krad}$. The levels of amylose content of all irradiated ones, regardless of genotypes and gamma irradiation doses (2 and $30 \mathrm{krad})$ were higher than that of control. In most parameters, irradiated Adira 4 was superior to irradiated Iding.
\end{abstract}

Keywords: Indonesian cassava, yield, starch, amylose content, RAPD

\footnotetext{
${ }^{*}$ Corresponding author:

Research Centre for Biotechnology - Indonesian Institute of Sciences (LIPI)

Jl. Raya Bogor Km 46 Cibinong 16911

Tel. +62-21-8754587, Fax. +62-21-87554588
}

\section{Introduction}

The importance of cassava (Manihot esculenta Crantz) as a staple food for more than 600 million people in the tropical world relies on the large amount of starch accumulated in its storage root. The cassava storage root (CSR) is made up of about $85 \%$ starch, $1 \%$ proteins (dry weight base), and a few other nutrients (Uchechukwu-Agua, et al., 2015, Kaur \& Ahluwalia, 2017, Carvalho, et al., 2019). Cassava starch has been considered as an important raw material for the industry and is the major area of targeted research for modern biotechnology in cassava (Chavarriaga-Aguirre et al., 2016). In Indonesia, the demand for cassava roots increased per year and they become an important commodity for food security (FAO, 2018). However, the growth of the plantation area has been negative i.e. $-0.48 \%$ indicating the area used to be cassava plantation has been converted to others despite the large areas of Indonesia and the issue of alternative energy. As a consequence, Indonesia has still become one of the importer countries for cassava starch as the export in 2002 was 20,082 tons while the import was 25,754 tons (Indonesia Ministry of Agriculture, 2016). Thus, various efforts to increase the cassava starch quality and production are being extensively pursued.

Cassava starch structure and functionality variability are the results of genetic factors, environmental factors, and more recently by genetic manipulation (Cabral \& Carvalho, 2000, Chaweewan \& Taylor, 2015, Opabode, 2018; Karlström et al., 2019). The genetic diversity in amylose proportion in the world germplasm collection, however, was considered to be low (Koehorst-van Putten et al., 2012) and variation in amylopectin structure has never been taken into consideration. In addition, the sources of plant mutations found in naturally occurring 
variation as well as obtained by induced mutation, such as an amylose free starch mutant of cassava (Ceballos et al., 2007, Karlström et al., 2016, Yani et al., 2017, Subekti et al., 2017) had no genetic analyses, yet.

A mutation is the most important single deterministic factor that produces a stable starch characteristic across plant generations.

Recently, the effects of gamma-irradiated on other Indonesian genotypes have been reported. However, none of them assessed the same genotypes and very limited of that on amylose content (Damaita et al., 2018; Khumaida et al., 2015). In other work on Latin American and African cassava, gamma irradiation was applied to stem cuttings to obtain high resistance to post-harvest physiological deterioration (PPD) due to fungi (Nwachukwu \& Adamu, 2009) or to reduce cyanide $(\mathrm{HCN})$ content (Oyeyemi \& Lawal, 2010).

The mutant induction combined with the molecular-based selection approach is a powerful technology to accelerate the genetic diversification in cassava. Random Amplification of Polymorphic DNA (RAPD) is one of the adapted techniques for the rapid detection of DNA genomics in organisms with short primer. This technique has been used in many plant species to detect genetic variation in wheat (Al-Tamimi \& Al-Janabi, 2019), yardlong bean (Pidigam et al., 2019), and yam (Rao et al., 2020). Cassava genetic studies using RAPD has been successfully reported on 31 Brazilian cassava clones (Colombo et al., 1998; Colombo et al., 2000a) and the genetic relatedness between cassava and two naturally occurring species (M. flabellifolia and $M$. peruviana) which are probably involved in the evolution of cassava (Colombo et al., 2000b). It has been also reported that the RAPD technique using primer OPB-10 and OPE-15 could detect the genetic diversity in 108 cassava genotypes of Indonesia (Sudarmonowati et al., 2006).

In this study, we reported the variation of amylose proportion in Iding and Adira 4 of induced cassava mutants derived from irradiated stem cuttings using a rapid method detection combined with other spectrophotometer analysis. Iding is known as a local cassava genotype with sweet taste and high amylose content (Anggraini et al., 2009), while Adira 4 is one of 15 Indonesia's varieties of cassava that have been used as a model for various research propagation through somatic embryogenesis and genetic transformation due to its responsiveness (Khumaida et al., 2015). The role of genotypes and dosages as well as propagation generation of irradiation were discussed. This study aimed to obtain superior traits related to cassava yield and starch, more specifically on amylose content obtained through mutant induction.

\section{Materials and Methods}

\section{Plant Material and Induced Mutation.}

Stem cuttings of two different cassava genotypes i.e. Adira 4 and Iding with the size approximately $20 \mathrm{~cm}$ consisting of 3 nodes which were irradiated at the dose of 2, 20,30, and $50 \mathrm{krad}$ at the National Nuclear Energy Agency of Indonesia. Each dose consisted of 50-400 stem cuttings. All plants (M1) were maintained or grown in the experimental field at Research Center for Biotechnology, LIPI. The stem plants were then propagated and harvested at 9-10 months old up to four generations (M1.V1-M1.V4). We focused on assessing the fourth generation (M1.V4) since the yield results were stable and to hinder chimera (Sholihin et al., 2019).

Stem cuttings at a normal size around 20 cm containing 4-5 nodes were planted directly in the field in a hole containing manure (goat manure) and were fertilized by Urea : TSP: $\mathrm{KCl}$ at 1 and 3-month-old after planting.

\section{Mutant Selection and Identification.}

The irradiated mutant lines were selected based on the survival rate and morphological performances followed by molecular genetic analysis using Random amplification of polymorphic DNA (RAPD) assay. RAPD analyses of control and irradiated plants were conducted. Procedures for RAPD analyses were the same as previously applied and have worked for analysing other Indonesian cassava genotypes conducted at the Research Centre for Biotechnology-LIPI (Sudarmonowati et al., 2006). The primer used was OPB-10 which has been proven suitable for assessing the genetic diversity of Indonesian cassava genotypes (Sudarmonowati et al., 2006). PCR conditions used were as follows: pre PCR at $94{ }^{\circ} \mathrm{C}$ for 3 min, followed by 40 cycles of denaturation at $94{ }^{\circ} \mathrm{C}$ for $12 \mathrm{sec}$, annealing at $35{ }^{\circ} \mathrm{C}$ for 24 
sec, and extension $72^{\circ} \mathrm{C}$ for $2 \mathrm{~min}$. Then, post PCR was performed at $72{ }^{\circ} \mathrm{C}$ for 7 minutes.

\section{Yield and Starch Content Analysis.}

Yield component analysis was observed in the fourth generation of irradiated lines i.e. the number of roots per plant, root fresh weight per plant, underwater weight per line number, root shape, and size. Dry matter and starch content values which were based on underwater weight, were calculated using the following formula : \% dry matter $=(158.3 \mathrm{x}$ $\mathrm{Sg})-142.0 ; \%$ starch $=(112.1 \mathrm{x} \mathrm{Sg})-106.4$; while $\mathrm{Sg}=\mathrm{A} / \mathrm{A}-\mathrm{B} ; \mathrm{A}=$ total fresh weight on air; $\mathrm{B}=$ weight under the water. Ideally, the total fresh weight measured is between 3 to 5 $\mathrm{kg}$ to obtain a more accurate estimation. Since some individuals yielded less than $1 \mathrm{~kg}$, these samples were also measured. The starch content analysis of irradiated lines was measured. The inner root of irradiated lines were stained with Lugol (diluted 1:3 with water). The range of staining patterns from the stained samples were observed. The starch isolation was conducted by peeling and homogenizing tuberous root samples in a grinder directly after harvest. The sediment was then washed several times with water and dried at room temperature for several days. While the amylose content was determined with a spectrophotometer following the method described by Koehorst-van Putten et al. (2012).

\section{Data Analysis.}

The growth parameters i.e. the umber of roots, the weight of roots, fresh weight of roots were collected and analysed based on average \pm standard deviation. The correlation analysis of fresh weight and starch content was conducted using Pearson correlation analysis by SPSS statistics program 2016.

\section{Results}

\section{Growth and Morphological Performances of Irradiated Plants.}

Around 50-400 stem cuttings of two cassava genotypes (Iding and Adira 4) were exposed to irradiation with the dose range between 2 and $50 \mathrm{krad}$. The stem cuttings were then planted at field plots and observed their survival rates and morphological performances to investigate the desired mutant candidates. Of those dosage applied to the plants, Adira 4 irradiated with the dose of 2 and $30 \mathrm{krad}$ as well as Iding with a dose of $2 \mathrm{krad}$ appeared to be potential mutant candidates for further cultivation, although the mutation rates of those mutant candidates were relatively low compared to those of initial stem cuttings before irradiation exposure (Table 1). On the other hand, another irradiated-dose application i.e. 20 and $50 \mathrm{krad}$ to those two cassava genotypes showed no good growth performances at the dose of 20 and tended to have abnormal growth and died at the dose of $50 \mathrm{krad}$, especially Adira 4 and Iding with the dose of 20 and $50 \mathrm{krad}$ (Figure 1). These findings might be related to the different responses of the cassava genotypes to irradiated treatment.

\section{Genetic Analysis of Irradiated Plants Based on RAPD.}

Three putative mutant lines possessing the desired mutation related to yield production were subjected for RAPD analysis using OPB10 primers. Results revealed that irradiated Adira 4 lines with a dose of $2 \mathrm{krad}$ had a different banding pattern with that of nonirradiated plant (control) (Figure 2). It appeared that irradiated Adira 4 at the dose of $2 \mathrm{krad}$ had no band of around $2000 \mathrm{bps}$ compared to that in control (Figure 2a). However, the resolution of those bands visualisation was not high enough. As a comparison, we conducted the same primer in irradiated Adira 4 exposed to $20 \mathrm{krad}$ irradiation. It showed that these irradiated plants have slightly different banding patterns as that of non-irradiated plants (Figure 2b). It revealed that OPB-10 random primer was still suitable for detecting the genetic diversity of cassava although the image profile needs to be optimized by increasing the quality and quantity of DNA and using another selective amplification primer pair. These irradiated Adira 4 mutant lines Numbers 8, 39, and 50 with the dose of $2 \mathrm{krad}$ showing the lost band pattern and altered band position compared to control which indicated the difference with control which explained some abnormalities. 
Table 1. The mutation rate of two irradiated cassava genotypes

\begin{tabular}{lccc}
\hline Genotype/dosage & $\begin{array}{c}\text { Number of } \\
\text { irradiated stem cutting }\end{array}$ & $\begin{array}{c}\text { Number of } \\
\text { putative mutant }\end{array}$ & $\begin{array}{c}\text { Mutation } \\
\text { rate (\%) }\end{array}$ \\
\hline Adira 4 (2 krad) & 200 & 5 & 2 \\
Iding (2 krad) & 200 & 6 & 3 \\
Adira 4 (30 krad) & 400 & 33 & 8.25 \\
\hline
\end{tabular}
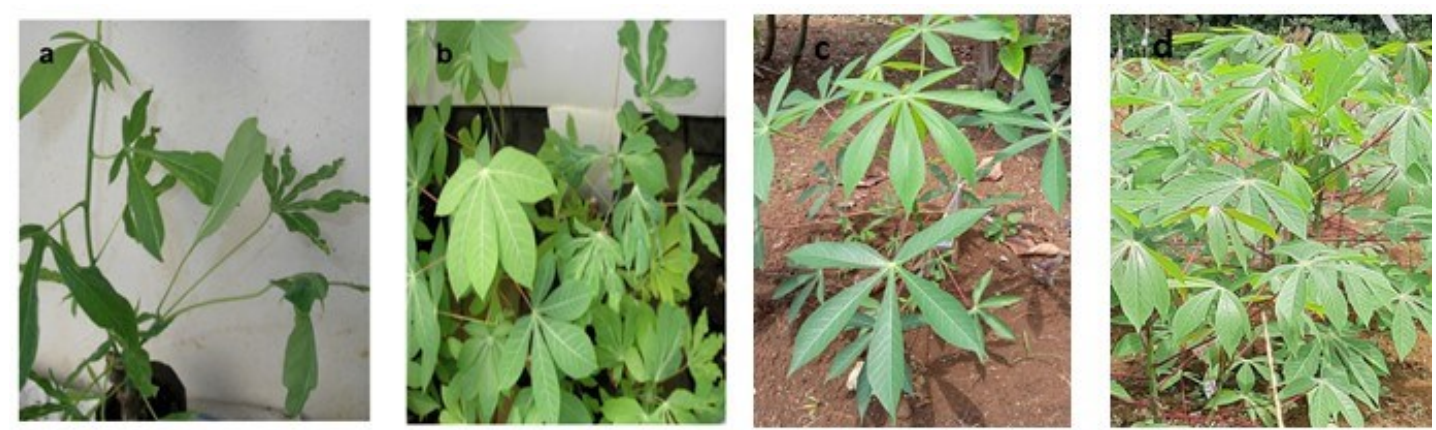

Figure 1. The abnormalities leaves of cassava after irradiated exposure. a) Malformation of Adira 4 leaves irradiated with $50 \mathrm{krad}$ and b) leaf variations of Iding with dose of $50 \mathrm{krad}$ as compared to c) Adira 4 control and d) Iding control.
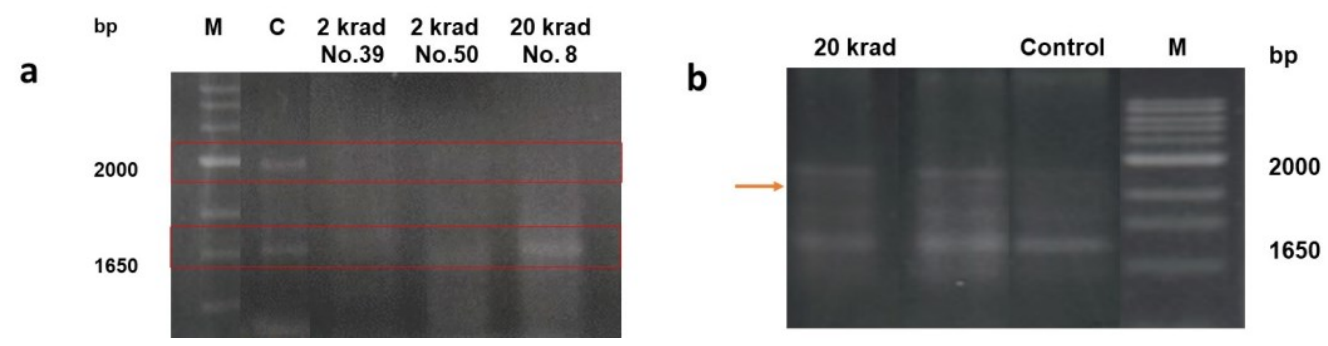

Figure 2. The band visualisation of irradiated and non-irradiated (control) plants by RAPD analysis using OPB-10 primer. a) Irradiated Adira 4 lines with a dose of 2 krad showing the lost band pattern and altered band position compared to control; b) Adira 4 exposed to $20 \mathrm{krad}$ irradiation showing slightly different banding patterns as that of control as indicated with arrow position. M: marker, C: non-irradiated plant as control.

\section{Yield Characteristics and Production.}

The survived mutant lines further grown at the field plot for 9 months were observed for their morphological performances. In the first generation of field-grown plants, it seemed that plants showed unstable yield production based on observation and as reported in other plants. Therefore, the stem cuttings were conducted until the fourth generation. Based on morphological performances related to the yield potential including the height of plants, the number of roots, and the size of roots as compared to the control(non-irradiated plant) (Figure $3 \& 4$ ), several mutant lines had been selected for further analysis especially their yield production, starch content and amylose content (Table 2 and Figure 6).
Based on the yield potential characteristics, irradiated Adira 4 lines with the dose of 2 and $30 \mathrm{krad}$ exhibited more number of roots than that of control (Figures 2 a \&b). In addition, the size of roots in both lines was also bigger than that of control. Interestingly, the irradiated Iding with a dose of $2 \mathrm{krad}$ also performed the same characteristics as Adira 4 mutant lines, especially the size of their roots was bigger than that of control (Figure 2c). It means that both irradiated Adira 4 and Iding mutant lines potentially have higher yield production, which might also possess high starch contents as well as the desired ratio of amylose and amylopectin contents. 


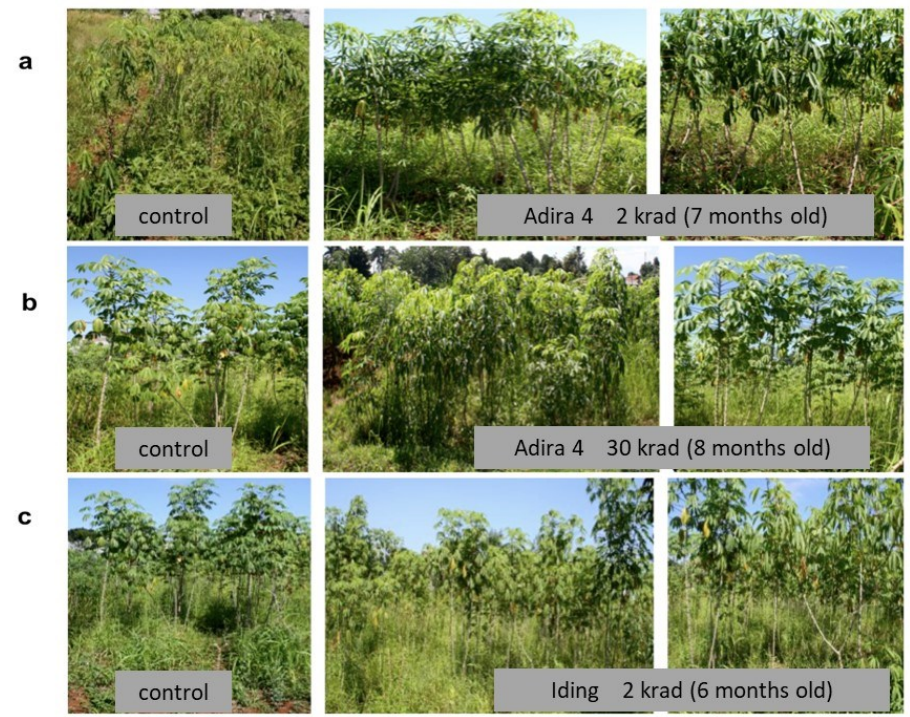

Figure 3. The growth performances of the fourth generation of field-grown irradiated plants as compared to control (non-irradiated plants). a) The 7-month old-field grown of Adira 4 with a dose of $2 \mathrm{krad}$ compared to control; b) the 8-month old-field grown of Adira 4 with a dose of $30 \mathrm{krad}$; c) the 6month-old of irradiated Iding $2 \mathrm{krad}$.
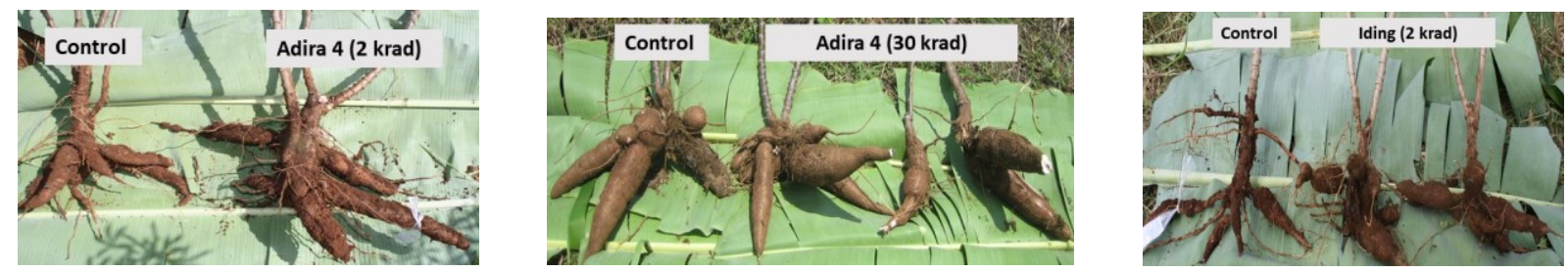

Figure 4. Selected mutant lines based on yield potential and other characteristics. These putative mutant lines were selected from 400 lines and grown in the field at the third generation. Root performances of Adira 4 with a dose of $2 \mathrm{krad}$ compared to control (left figure); root characteristics of Adira 4 with a dose of $30 \mathrm{krad}$ (middle figure); roots performances of irradiated Iding $2 \mathrm{krad}$ as compared to control (right figure).

\section{Yield and Starch Contents.}

The yield and starch content of irradiated plants were analysed after the fourth generation of field-grown. The initial starch test was conducted by staining the inner part of the tuberous root section of several irradiated cassava lines (Figure 5). The test revealed that irradiated Adira 4 with a dose of $2 \mathrm{krad}$ exhibited dark blue colour in all inner parts of the root section, which was similar to the control. Meanwhile, the staining colour of irradiated Adira 4 with a dose of $30 \mathrm{krad}$ showed $90 \%$ dark blue, while the control seemed $75 \%$ light blue (Table 2.). The higher colour intensity of Lugol staining of irradiated plants was also correlated with the higher estimated and extracted starch content. On the other hand, in irradiated Iding with a dose of 2 $\mathrm{krad}$, several lines showed the same dark blue colour as that of control, but not all root sections were stained (20-60\% stained roots). These rapid Lugol tests might correlate with the type of granule starch and amylose content of the roots. However, these tests could not be used as the main deduction without other biochemical analyses. 


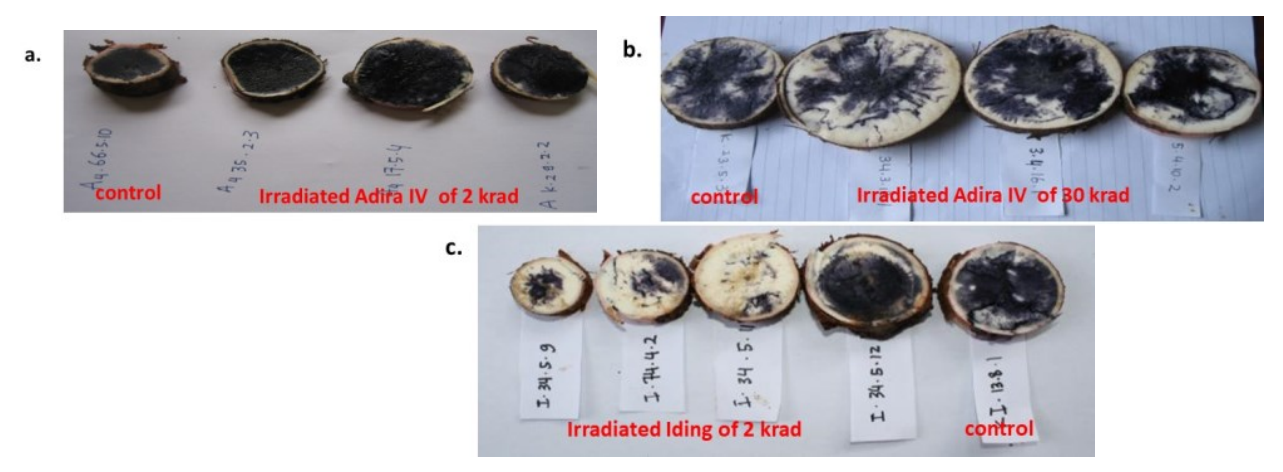

Figure 5. The stained tuberous root section of several irradiated cassava lines. a) Irradiated Adira 4 with a dose of $2 \mathrm{krad}$ compared to control; b) Irradiated Adira 4 with a dose of $30 \mathrm{krad}$ compared to control; c) Irradiated Iding with a dose of $2 \mathrm{krad}$ compared to control. Each staining test consisted of 4 -5 different lines of irradiated cassava with contrast stained root results.

Table 2. Lugol test of irradiated plants and control of Adira 4 and Iding

\begin{tabular}{lcc}
\hline Individual & $\begin{array}{l}\text { \% of samples } \\
\text { exhibit dark blue }\end{array}$ & \% of samples exhibit light blue \\
lines/genotype & & 60 \\
\hline Adira 4 (2 krad) & 40 & 60 \\
Adira 4 (30 krad) & 90 & 50 \\
Adira 4 (Control) & 75 & 57 \\
Iding (2 krad) & 43 & 75 \\
Iding (Control) & 25 & \\
\hline
\end{tabular}

Of the yield production, it showed that induced mutants of all selected lines of irradiated Adira 4 stem cuttings possessed higher fresh weight and starch content than those of control (Table 3). The average starch content of Adira 4 mutants varied depending on the lines i.e. $24.70 \%-27.89 \%$ and of extracted starch was $23.56 \%-25.34 \%$, while that of control was $18.16 \%$ and $14.15 \%$, respectively. The yield of a certain line of mutants was also higher than that of control, regardless of the genotypes planted. Likewise, irradiated Iding at the fourth generation was higher than control in terms of starch content (Table 3).

Table 3. Mean growth and starch weight of the fourth generation of irradiated cassava harvested at 9 months in the field

\begin{tabular}{lccccc}
\hline $\begin{array}{c}\text { Individual } \\
\text { lines/genotype }\end{array}$ & $\begin{array}{c}\text { Number of } \\
\text { samples }\end{array}$ & $\begin{array}{c}\text { Fresh weight } \\
(\mathbf{g})\end{array}$ & $\begin{array}{c}\text { Root } \\
\text { number }\end{array}$ & $\begin{array}{c}\text { Estimated } \\
\text { starch content } \\
(\%)\end{array}$ & $\begin{array}{c}\text { Extracted } \\
\text { starch }(\%)\end{array}$ \\
\hline Adira 4 $(2 \mathrm{krad})$ & 12 & $893.8 \pm 537.8$ & $3.1 \pm 1.41$ & $27.9 \pm 5.7$ & $25.16 \pm 3.5$ \\
Adira 4 (30 krad) & 22 & $1204.6 \pm 806.4$ & $3.27 \pm 2.83$ & $24.7 \pm 5.8$ & $23.56 \pm 2.8$ \\
Adira 4 (Control) & 10 & $585.0 \pm 428.9$ & $3.1 \pm 0.71$ & $18.2 \pm 5.9$ & $14.6 \pm 3.0$ \\
Iding (2 krad) & 17 & $686.8 \pm 277.3$ & $3.12 \pm 0.71$ & $18.1 \pm 6.2$ & $26.5 \pm 4.3$ \\
Iding (Control) & 6 & $625 \pm 294.5$ & $2.33 \pm 1.41$ & $16.3 \pm 7.1$ & $22.7 \pm 7.6$ \\
\hline
\end{tabular}

In order to investigate the correlation between the fresh weight and the starch content of those mutant lines, we analysed those parameters using the Pearson correlation. Results showed that both fresh weight and starch contents had a positive and close correlation in each of the mutant lines and their corresponding control (Table 4). Interestingly, in Adira $4(2 \mathrm{krad})$, both parameters had a significantly negative correlation. This means that if the fresh weight of this line is high, the starch content will be low and vice versa. 
Table 4. The correlation analysis of fresh weight and starch content parameters of each mutant lines and their corresponding control

\begin{tabular}{|c|c|c|c|c|c|c|c|c|c|c|}
\hline & $\begin{array}{l}\text { FW Ad4 } \\
\text { (2krad) }\end{array}$ & $\begin{array}{l}\text { FW Ad } 4 \\
\text { (30krad) }\end{array}$ & $\begin{array}{l}\text { FW Ad } 4 \\
\text { (ctrl) }\end{array}$ & $\begin{array}{l}\text { FW Id } \\
\text { (2 krad) }\end{array}$ & $\begin{array}{l}\text { FW Id } \\
\text { (ctrl) }\end{array}$ & $\begin{array}{l}\text { SC Ad } 4 \\
\text { (2krad) }\end{array}$ & $\begin{array}{l}\text { SC Ad } 4 \\
\text { (30krad) } \\
\end{array}$ & $\begin{array}{l}\text { SC Ad4 } \\
\text { (ctrl) }\end{array}$ & $\begin{array}{l}\text { SC Id } \\
\text { (2krad) } \\
\end{array}$ & $\begin{array}{l}\text { SC } \\
\text { Iding } \\
\text { (ctrl) } \\
\end{array}$ \\
\hline $\begin{array}{l}\text { FW Ad } 4 \\
\text { (2krad) }\end{array}$ & 1 & -0.961 & -0.482 & -0.693 & 0.994 & $.998^{*}$ & 0.701 & -0.654 & -0.694 & 0.836 \\
\hline $\begin{array}{l}\text { FW Ad } 4 \\
\text { (30krad) }\end{array}$ & & 1 & 0.706 & 0.866 & -0.924 & -0.944 & -0.871 & 0.838 & 0.867 & -0.956 \\
\hline $\begin{array}{l}\text { FW Ad } 4 \\
\text { (ctrl) }\end{array}$ & & & 1 & 0.966 & -0.383 & -0.432 & -0.963 & 0.978 & 0.965 & -0.883 \\
\hline $\begin{array}{l}\text { FW Id (2 } \\
\text { krad) }\end{array}$ & & & & 1 & -0.61 & -0.652 & $1.000^{*}{ }^{-}$ & $.999 *$ & 1.000 ** & -0.975 \\
\hline $\begin{array}{l}\text { FW Id } \\
\text { (ctrl) }\end{array}$ & & & & & 1 & $.999 *$ & 0.619 & -0.567 & -0.611 & 0.771 \\
\hline $\begin{array}{l}\text { SC Ad } 4 \\
\text { (2krad) }\end{array}$ & & & & & & 1 & 0.66 & -0.611 & -0.653 & 0.805 \\
\hline $\begin{array}{l}\text { SC Ad } 4 \\
\text { (30krad) }\end{array}$ & & & & & & & 1 & $-.998 *$ & $-1.000 * *$ & 0.977 \\
\hline $\begin{array}{l}\text { SC Ad } 4 \\
\text { (ctrl) }\end{array}$ & & & & & & & & 1 & $.999 *$ & -0.962 \\
\hline $\begin{array}{l}\text { SC Id } \\
\text { (2krad) }\end{array}$ & & & & & & & & & 1 & -0.975 \\
\hline SC Id(ctrl) & & & & & & & & & & 1 \\
\hline
\end{tabular}

Note: FW: fresh weight; SC: starch content. * means the correlation is significant at the 0.05 level, while ** means the correlation is significant at the 0.01 level. The yellow colour highlighted the correlation of both parameters in each mutant line.

\section{Amylose Content.}

Several selected lines showing the unique colour and covered staining area from the previous staining tests were further subjected to amylose content analysis. Results showed that the amylose content of all irradiated cassava plants in both Adira 4 and Iding was higher than that of control. However, Adira 4 regardless of the generation seemed to be superior to Iding in terms of amylose content. Amylose content of M1V4 generation derived from $2 \mathrm{krad}$ irradiated Iding ranged from 33.32 $-34.66 \%$. Whereas, amylose content of $2 \mathrm{krad}$ irradiated Adira 4 was $33.77 \%-37.66 \%$. The lowest range of amylose contents was in 30 krad irradiated Adira 4 ranging from 30$32.72 \%$ (Figure 6).
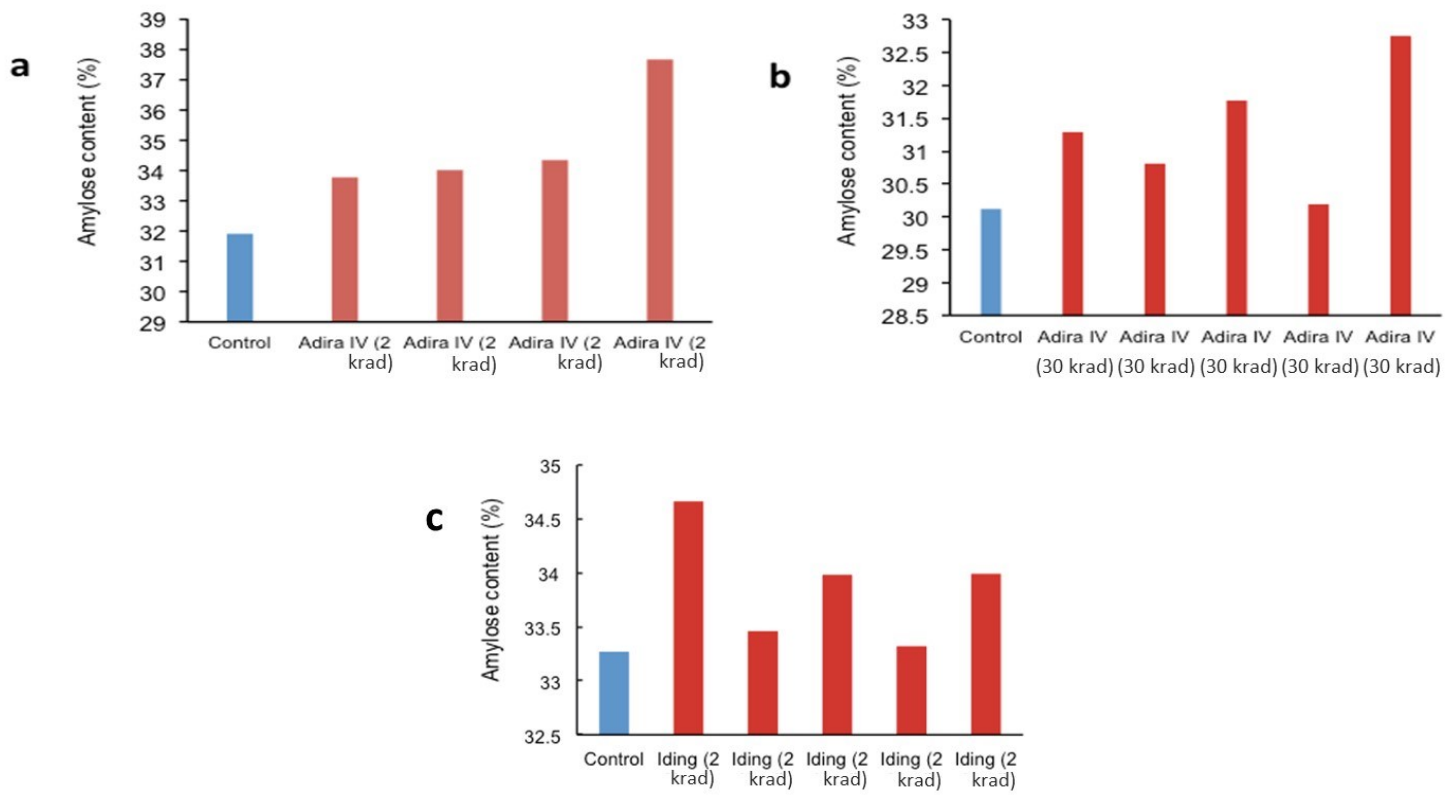

Figure 6. The amylose content of the fourth generation of field-grown irradiated and non-irradiated (control) cassava stem. 


\section{Discussion}

Gamma-ray irradiation has been proven as a valuable tool to induce variations in plants. This technique combined with the molecular approach has successfully induced sweet potato producing high yield and starch content (Shin et al., 2011) and improved digestibility of Kithul (Caryota urense) starch (Sudheesh et al., 2019). In this study, Iding stem cuttings irradiated at a higher dose than $2 \mathrm{krad}$ did not produce shoots compared to that of Adira 4. Doses at higher than $30 \mathrm{krad}$ have led to leaf malformation and abnormal growth. The dose at around 1-1.5 krad was also the most appropriate one used for irradiated stem cuttings of South American and African cassava for obtaining trait of interest (Oyeyemi \& Lawal, 2010). Other Indonesian genotypes used doses as low as 0.15 to $0.20 \mathrm{krad}$ depending on the materials used (Damaita et al., 2018). These indicated that Adira 4 might be more tolerant to water loss and irradiation treatment compared to others. In terms of acute dose, it seemed that a dose of above $30 \mathrm{krad}$ inhibited the growth of the plants, which could be observed from severe malformed leaves and a low percentage of survival rate (Table 1 and Figure 1). However, for Adira 4, this dose has given a positive effect on increased yield as the mean weight of individuals was more than twice of that of control and almost 1.5 times of that irradiated with $2 \mathrm{krad}$ (Table 3). This indicated that the irradiation dose determined the target trait.

The mutation rate of the plants was considered low (Table 1). This might be due to the effect of genotypes and the planting material used. Iding and Adira 4 have given different responses toward irradiation than other Indonesian genotypes as reported in earlier publications. Different genotypes such as Gebang and different irradiated planting material had different responses to irradiation (Supatmi \& Sudarmonowati, 2012b; Supatmi et al., 2016, Sholihin \& Mejaya, 2019). These results were in line with other researches, reporting that the effective irradiation application to seeds or propagated plants should be in the range between 60 Gy to 700 $\mathrm{Gy} / 6 \mathrm{krad}$ to $70 \mathrm{krad}$, while the in vitro material ranged $0.2 \mathrm{krad}-0.5 \mathrm{Krad}$ depending on plant genotypes and environmental factors (Ahloowalia \& Maluszynski, 2001; Supatmi \& Sudarmonowati, 2012a; Supatmi \&
Sudarmonowati, 2012b; Supatmi et al., 2016).

To confirm the changes of irradiated plants as a response to irradiation, molecular identification using the RAPD marker was conducted to complement the morphological identification. It revealed that Adira 4 with a dose of $2 \mathrm{krad}$ had lost the banding visualisation at a size of $2000 \mathrm{bps}$ compared to Adira 4 (control) by employing OPB-10 random primer (Figure 2). As a comparison, we also conducted the same analysis to irradiated Adira 4 with a dose of $20 \mathrm{krad}$ showing the same band pattern as control. Although the band resolution was low, the differences in the band pattern were still clearly observed. The use of OPB-10 as a suitable primer for cassava molecular identification had been successfully reported (Sudarmonowati et al., 2006), although the other factors such as the DNA quality and the PCR condition of each plant might cause different results. Further analysis by employing other random primers with good quality of DNA, however, is suggested.

The target of the desired mutation in plants resulting from irradiation treatments is different in each plant. In cassava, the high yield production and the high starch content as well as the good ratio of amylose and amylopectin contents are mainly aimed. Several mutant lines of Adira 4 (2 and $30 \mathrm{krad}$ ) and Iding $(2 \mathrm{krad})$ showed the potential in yield production in terms of the height, number, and size of roots (Figure 3 \& 4) compared to those of their representative controls. In addition, both Adira 4 (2 and 30 krad) had the highest fresh weight compared to those of Iding and their representative control (Table 3). However, the starch content analysis showing that Iding with a dose of $2 \mathrm{krad}$ had the highest starch content followed by Adira 4 $(2 \mathrm{krad})$. This result was in line with the results of correlation analysis, showing that both parameters had a positive correlation in each mutant line except in Adira 4 (2 krad) exhibiting the negative correlation. This different response might confirm that the fresh weight of the roots is not the determinant factor to estimate the starch content. Zhu (2015) reported that the fresh weight might attribute to the starch purity and the extraction efficiency of cassava. On the other hand, the starch content was not also in accordance with 
the results of the staining Lugol test, showing several Iding lines exhibited low coverage area of Lugol staining. Therefore, another biochemical analysis must be conducted as supporting analysis.

The amylose content in starch is of importance to determine the functional properties of cassava starch for further base starch industry. In this study, we found that the amylose content of selected mutant lines of Iding and Adira 4 were higher compared to those representative controls. In terms of genotype and irradiation dose, it seemed that the amylose content of Adira 4 (2 krad ) was the highest one followed by Iding ( $2 \mathrm{krad})$ and Adira $4 \quad(30 \mathrm{krad})$. These findings are promising to be further developed, although the stability of their amylose contents and starch contents should be further evaluated.

Naturally, the proportion of amylose in cassava $17-25 \%$ of starch while amylopectin is $75-80 \%$ (Opabode, 2018). Based on that proportion, it appeared that Adira 4 and Iding, originally, possessed high amylose than the common amylose content in cassava. Several individuals of irradiated Iding showed less amylose indicated by almost no blue-stained tuber flesh which might be useful for non-food industrial materials such as textiles and paper which require low amylose or even amylosefree starch (Figure 5c). This clearly confirmed that the genotype/cultivar had an impact on the amylose content besides other environmental factors such as altitude (Subekti et al., 2017; Setiawan \& Rahmawati, 2019) and water or season (Gu et al., 2013).

In this study, we highlighted the findings of improved starch quality of two different genotypes of cassava through gamma irradiation. The response of plants to irradiation treatment was varied depending on genotypes used for irradiation, gammairradiation dose, and generation of propagation. The irradiated treatment combined with a molecular approach such as RAPD could be a superior tool to induce the desired mutation in cassava especially related to the potential yield including the starch and amylose contents. We found that irradiated Adira 4 (2 and $30 \mathrm{krad}$ ) and Iding $(2 \mathrm{krad})$ exhibited higher yield and amylose content compared to their representative controls. These could be further developed by characterizing in-depth their starch composition, structure, physicochemical properties, and modifications, which highly contribute to the cassava starch-based industry in the future.

\section{Acknowledgements}

We would like to thank the NAEA of Indonesia for irradiating Indonesian cassava materials. We also would like to thank IAEA Project No. 13196/R3 for Indonesia which was part of "Molecular Tools for Quality Improvement in Vegetatively Propagated Crops Including Banana and Cassava (D23027) and the FAO/IAEA Joint Programme for partly financial support for the work.

\section{References}

Ahloowalia, B. S., \& Maluszynski, M. (2001). Induced mutations-A new paradigm in plant breeding. Euphytica, 118(2), 167-173.

Anggraini, V., Sudarmonowati, E., Hartati, N. S., Suurs, L., \& Visser, R. G. (2009). Characterization of cassava starch attributes of different genotypes. Starch-Stärke, 61(8), 472481.

Al-Tamimi, A. J., \& Al-Janabi, A. S. (2019). Genetic diversity among bread wheat genotypes using RAPD and SSR markers. SABRAO Journal of Breeding and Genetics, 51(3), 325339.

Cabral G.B., \& Carvalho L.J.C.B. (2000) The Formation of Storage Root in Cassava. In Carvalho LJCB, Thro AM, Vilarinhos AD (eds), Cassava Biotechnology. Proceedings of IVth International Scientific Meeting - CBN.. Published by Embrapa-Recursos Genéticos e Biotecnologia. Brasília-DF, Brazil, pp 345-356.

Carvalho, L. J., Anderson, J. V., da Silva, J. P., Chen, S., \& de Souza, C. R. (2019). Protein content in cassava storage root is associated with total abundance of carotenoids. International Research Journal Plant Science, 10(1), 1-11. http:/dx.doi.org/10.14303/irjps.2019.003

Ceballos, H., Sánchez, T., Morante, N., Fregene, M., Dufour, D., Smith, A. M., Denye, K. Pérez, C, Calle, F. \& Mestres, C. (2007). Discovery of an amylose-free starch mutant in cassava (Manihot esculenta Crantz). Journal of Agricultural and Food Chemistry, 55(18), 74697476.

Chavarriaga-Aguirre, P., Brand, A., Medina, A., Prías, M., Escobar, R., Martinez, J., Díaz, P., López, C., Roca, W. \& Tohme, J. (2016). The potential of using biotechnology to improve cassava: a review. In Vitro Cellular \& 
Developmental Biology-Plant, 52(5), 461-478.

Chaweewan, Y., \& Taylor, N. (2015). Anatomical Assessment of Root Formation and Tuberization in Cassava (Manihot esculenta Crantz). Tropical Plant Biology. 8, 1-8. https://doi.org/10.1007/ s12042-014-9145-5

Colombo, Carlos, Second, Gerard, Losada, V. Tereza \& Charrier, Andre (1998). Genetic diversity characterization of cassava cultivars (Manihot esculenta Crantz).: I) RAPD markers. Genetics and Molecular Biology 21(1). DOI:10.1590/S1415-47571998000100018

Colombo, Carlos, Second, Gerard \& Charrier, Andre. (2000a). Diversity within American cassava germ plasm based on RAPD markers. Genetics and Molecular Biology, 23(1), 189199.

Colombo, Carlos, Second, Gerard \& Charrier, Andre. (2000b). Genetic relatedness between cassava (Manihot esculenta Crantz) and $M$. flabellifolia and $M$. peruviana based on both RAPD and AFLP markers. Genetics and Molecular Biology, 23(2), 417-423.

Damaita, Iz, Lestari, Tri, Apriyadi, Rion. (2018). Influence gamma ray irradiation in tuber quality of three accession cassava (Manihot esculenta Crantz) origin of Bangka. Agrosainstek 2 (2):53-60

De Souza, CRB, Carvalho, L.J.C.B., De Almeida, E.R.P. \& Gander, E.S. (2002). Identification of cassava root protein genes. Plant Foods for Human Nutrition 57: 353-363, Kluwer Academic Publishers. Printed in the Netherlands.

FAO. 2018 Food Outlook - Biannual Report on Global Food Markets - November 2018. Rome. 104 pp. Licence: CC BY-NC-SA 3.0 IGO

Gu, B., Yao, Q., Li, K., \& Chen, S. (2013). Change in physicochemical traits of cassava roots and starches associated with genotypes and environmental factors. Starch-Starke, 65(3-4), 253-263.

Indonesia Ministry of Agriculture. 2016. Outlook Komoditas Pertanian Tanaman Pangan Ubi Kayu. Jakarta (ID): Indonesia Ministry of Agriculture.

Karlström, A., Calle, F., Salazar, S., Morante, N., Dufour, D., \& Ceballos, H. (2016). Biological Implications in Cassava for the Production of Amylose-Free Starch: Impact on Root Yield and Related Traits. Frontiers in plant science, 7, 1-8.

Karlström, A., Belalcazar, J., Sánchez, T., Lenis, J. I., Moreno, J. L., Pizarro, M. \& Ceballos, H. (2019). Impact of environment and genotype-by-environment interaction on functional properties of amylose-free and wildtype cassava starches. Starch-Stärke, 71(12), 1700278

Kaur, K. \& Ahluwalia, P. (2017). Cassava as potential Crop for the food and fermentation industry: A review. International Journal of Food and Fermentation Technology. 7(1): 1-12.

Khumaida, N., Ardiea, S.W, Dianasaria, M. and Syukur, M. (2015). Cassava (Manihot esculenta Crantz.) improvement through gamma irradiation. Procedia Food Science 3, 27-34

Koehorst-van Putten, H. J. J., Sudarmonowati, E., Herman, M., Pereira-Bertram, I. J., Wolters, A. M. A., Meima, H., ... \& Visser, R. G. F. (2012). Field testing and exploitation of genetically modified cassava with low-amylose or amylosefree starch in Indonesia. Transgenic research, 21(1), 39-50.

Nwachukwu, E. \& Adamu, L. (2009). Effects of gamma irradiation on post-harvest deterioration of cassava (Manihot esculenta Crantz) tuber by fungi. Fresh Produce, 3 (1): 71-75

Opabode, J. T. (2018). Bioengineering of cassava starch properties and associated tuber qualities using gene technology approach: progress and future directions. Current Biotechnology, 7(6), 409-416.

Oyeyemi, S.M \& Lawal A.O. (2010). Reduction of cyanide content in cassava by gamma irradiation from cirus cobol (60) teletherapy machine. Continental J. Applied Sciences 5: 69- 73

Pidigam, S., Munnam, S. B., Nimmarajula, S., Gonela, N., Adimulam, S. S., Yadla, H., Bandari, L \& Amarapalli, G. (2019). Assessment of genetic diversity in yardlong bean (Vigna unguiculata (L.) Walp subsp. sesquipedalis Verdc.) germplasm from India using RAPD markers. Genetic Resources and Crop Evolution, 66(6), 1231-1242.

Rao, G. K., Kapadia, C., Patel, N. B., Desai, K. D., \& Murthy, P. N. (2020). Genetic diversity analysis of greater yam (Dioscorea alata L.) genotypes through RAPD and ISSR markers. Biocatalysis and Agricultural Biotechnology, 23, 101495.

Shin, J. M., Kim, B. K., Seo, S. G., Jeon, S. B., Kim, J. S., Jun, B. K., Kang, S.Y, Lee, J.S., Chung, M.N., Kim, S.H \& Kim, S. H. (2011). Mutation breeding of sweet potato by gammaray radiation. African Journal of Agricultural Research, 6(6), 1447-1454.

Sholihin, K. N., \& Mejaya, M. J. (2019). Genotypic variability in cassava (Manihot esculenta Crantz) mutants (M1V4) using gamma irradiation. SABRAO Journal of Breeding and Genetics, 51(2), 107-116.

Subekti, I., Khumaida, N., \& Ardie, S. W. (2017). Identification of potentially high yielding irradiated cassava 'Gajah'genotype with different geographic coordinates. In IOP Conference Series: Earth and Environmental Science, 54(1), 012013. IOP Publishing.

Setiawan, A., \& Rahmawati, N. (2019). Identification of the morphophysiological characteristics of cassava (Manihot esculenta 
Crantz) Based on Altitude. In IOP Conference Series: Earth and Environmental Science,260(1), 012125). IOP Publishing.

Sudheesh, C., Sunooj, K. V., George, J., Kumar, S., \& Sajeevkumar, V. A. (2019). Impact of $\gamma^{-}$ irradiation on the physico-chemical, rheological properties and in vitro digestibility of kithul (Caryota urens) starch; a new source of nonconventional stem starch. Radiation Physics and Chemistry, 162, 54-65.

Sudarmonowati, E., N. S. Hartati, \& L. Sukmarini. (2006). Amylose content variation of Indonesian cassava genotypes and its correlation with RAPD and AFLP markers. Proceedings of the First International Meeting on Cassava Breeding, Biotechnology and Ecology, 85-95.

Supatmi \& Sudarmonowati, E. (2012a). Root morphology and yield variation of irradiated Mlg-10248 cassava multiplied by innovative ratooning technique. In Proceedings the 5th Indonesian Biotechnology Conference An International Forum. (pp 340-352). ISSN: 23018216.

Supatmi, S., \& Sudarmonowati, E. (2012b). Improved regeneration, acclimatization and shoot cutting production of "Gebang" cassava derived from irradiated in vitro shoots. Annales Bogorienses, 16(2),7-12.

Supatmi, Fitriani, H, Hartati, N.S., \&
Sudarmonowati, E. (2016). Variasi morfologi dan evaluasi daya hidup stek ubi kayu "MLG10248" asal radiasi biji hasil perbanyakan cepat dengan Teknik Ratooning. In Prosiding Seminar Nasional ke 56 Temu-Ilmiah Jaringan Kerjasama Kimia Indonesia. (pp. 269-274). ISSN: 0854-4778.

Supatmi, N. Sri Hartati \& Enny Sudarmonowati (2017) Extending shelf life through induced mutation using gamma-ray irradiation. In Proceedings of International Symposium on Bioeconomics of Natural Resources Utilization. (pp. 209-220). ISBN: 978-979-8539-77-0

Uchechukwu-Agua, A. D., Caleb, O. J., \& Opara, U. L. (2015). Postharvest handling and storage of fresh cassava root and products: a review. Food and Bioprocess Technology, 8(4), 729748.

Yani, R. H., Khumaida, N., Ardie, S. W., \& Syukur, M. (2017). Analysis of variance, heritability, correlation and selection character of M1 V3 generation cassava (Manihot esculenta Crantz) mutants. AGRIVITA, Journal of Agricultural Science, 40(1), 74-79.

Zhu, F. (2015). Composition, structure, physicochemical properties, and modifications of cassava starch. Carbohydrate polymers, 122, 456-480. 